\title{
The effects of HAP and macrophage cells to the expression of inflammatory factors and apoptosis in HK-2 cells of vitro co- cultured system
}

\author{
Junchuan $\mathrm{Yu}^{1} \cdot$ Yaoliang Deng ${ }^{1} \cdot$ Zhiwei Tao $^{1}$ - Weixia Liang ${ }^{1} \cdot$ Xiaofeng Guan ${ }^{1} \cdot$ Jihua Wu $^{1} \cdot \mathrm{Xin} \mathrm{Ning}^{1} \cdot$ Yunlong Liu $^{1}$. \\ Quan Liu ${ }^{1} \cdot$ Ziqi He ${ }^{1}$
}

Received: 27 April 2017 / Accepted: 11 November 2017 / Published online: 13 December 2017

(c) The Author(s) 2017. This article is an open access publication

\begin{abstract}
This study developed an in vitro system by co-culturing HK-2 cells with different concentration of hydroxyapatite (HAP) and/or macrophage cells to simulate the internal environment of urolithiasis as far as possible, investigating the regulatory effects of macrophage cells on HAP-induced expression of relative inflammatory factors of HK-2 cells. The control group (H group) was only comprised of HK-2 cells. Experimental groups included co-culturing HK-2 cells and macrophage cells ( $\mathrm{H}+\mathrm{M}$ group), co-culturing HK-2 cells and HAP ( + A group), co-culturing macrophage cells and $\mathrm{HAP}$ ( $\mathrm{M}+\mathrm{A}$ group), and co-culturing HK-2 cells and macrophage cells with $\mathrm{HAP}(\mathrm{H}+\mathrm{M}+\mathrm{A}$ group). In the $\mathrm{H}+\mathrm{A}, \mathrm{M}+\mathrm{A}$, and $\mathrm{H}+\mathrm{M}+\mathrm{A}$ group, we set the concentration of HAP as $5 \mu \mathrm{g} / \mathrm{cm}^{2}$ (A1) and $10 \mu \mathrm{g} / \mathrm{cm}^{2}$ (A2). After co-culturing for 2, 4 , and $6 \mathrm{~h}$, we detected the expression of CCL-2 in the liquid by ELISA. We tested the expression of LDH and ROS to evaluate the damage of HK-2 cells. We assessed the apoptosis of HK-2 cells using DAPI staining assay, flow cytometry, and the rate of BAX/BCL-2. Western Blotting detected OPN, Fetuin-A, BAX, and BCL-2 of HK-2 cells. The expression of CCL-2 in the medium of H+A1 and $\mathrm{H}+\mathrm{A} 2$ group increased significantly compared with the control $(P<0.05)$; $\mathrm{CCL}-2$ of $\mathrm{M}+\mathrm{A} 1$ and $\mathrm{M}+\mathrm{A} 2$ group was higher than the $\mathrm{H}+\mathrm{A} 1$ and $\mathrm{H}+\mathrm{A} 2$ group $(P<0.05)$. The expression of $\mathrm{CCL}-2$ in $\mathrm{H}+\mathrm{M}+\mathrm{A} 1$ and $\mathrm{H}+\mathrm{M}+\mathrm{A} 2$ group was also higher than $\mathrm{M}+\mathrm{A} 1$ and $\mathrm{M}+\mathrm{A} 2$ group $(P<0.05)$. Compared with control, the expression of OPN, LDH release, the ratio of $\mathrm{BAX} / \mathrm{BCL}-2$, and the generation of ROS in HK-2 cells increased in a dose- and time-dependent manner. Compared with the control, the expression of Fetuin-A decreased in various degrees at different incubation periods. Especially when co-culturing for $6 \mathrm{~h}$, Fetuin-A decreased most seriously in the H+M+A1 group. (1) The HAP can induce the HK-2 cells oxidative stress and inflammatory damage and apoptosis, when adding the macrophages to co-culture, macrophage cells can aggravate the damage and apoptosis of the HK-2 cells. (2) After the stimulation of HAP, the expression of OPN in HK-2 cells increased in a time- and dose-dependent manner; macrophage cells can aggravate the increase of OPN in HK-2 cells. (3) In the HAP and HK-2 cells co-cultured system, the low-level Fetuin-A of HK-2 cells may be related to the excessive consumption of Fetuin-A in the process of HAP-induced renal tubular epithelial cell excessive oxidative stress, inflammatory injury, and cell apoptosis. When adding macrophage cells to co-culture, Fetuin-A decreased even more seriously, it reminds us that macrophage cells can slightly regulate the expression of Fetuin-A in the HK-2 cells.
\end{abstract}

Keywords Macrophage cells $\cdot$ Hydroxyapatite $\cdot$ Renal tubular epithelial cells $\cdot$ Co-culture $\cdot$ Fetuin-A

\section{Introduction}

Junchuan Yu and Zhiwei Tao contributed equally to this study and co-first authors.

Electronic supplementary material The online version of this article (https://doi.org/10.1007/s00240-017-1032-8) contains supplementary material, which is available to authorized users.

Extended author information available on the last page of the article
Urolithiasis is a common disease in urology; about 5-15\% of people worldwide suffer from urolithiasis [1]. The recurrent urolithiasis can cause significant economic and medical implications [2], it also leads to a series of complications, such as metabolic syndrome, and chronic and terminal kidney diseases $[3,4]$. To explore the etiology and pathogenesis of urinary calculi has always been the hot spot of the urology 
research, at present, we generally believed that the interaction of genetic, diet, environment, and calcium metabolism abnormality participated in the formation and development of urolithiasis, the abnormal calcium metabolism includes the mineral heterogeneity nucleation, crystal growth aggregation, and the adhesion of the renal epithelial cells $[5,6]$. The most common stone in urolithiasis is calcium oxalate [7]. However, the formation mechanism of calcium oxalate calculi is still unknown.

Alexander Randall regraded calcium phosphate plaques in renal papillae as the origin of kidney stones [8]. The plaques which we called Randall's plaques (RP) originate deep inside the renal interstitium associated with the basement membranes of loops of Henle, and can promote the nucleation, growth, and aggregation of $\mathrm{CaO}_{x}$ crystals in renal epithelial cells [8]. Recent studies evidence that the number of calcium oxalate stone is proportional to the covered area of RP [9], but the main mineral phase of RP is seems to be irrelevant to calcium oxalate stones in the form of hydroxyapatite [10], so there is an unavoidable connection between hydroxyapatite and calcium oxalate stone. The release of inflammatory reaction caused by the infiltration of macrophages in the intercellular space of the crystals and the release of chemokine CCL-2 was also found to promote the formation of stones [11-14]. Macrophages can alter their function based on the activation program utilized-either M1 or M2 patterns [15]. M1 macrophages are thought to be antitumorigenic as well as be pro-inflammatory and antimicrobial, although this remains the subject of debate [15]. M2 macrophages are associated with wound healing and have pro-tumorigenic properties $[15,16]$. The inflammation which triggered by macrophage cells infiltration of the intercellular space around the crystals is also found to be the important process of stone formation [11]. C-C motif chemokine ligand 2 (CCL-2) is a chemokine and osteopontin (OPN) are also beneficial to urolithiasis [12-14]. Adhesion effect of OPN may inspire the process of stone crystal heterogeneous nucleation, and promote the formation of stones. Renal epithelial cell injury and apoptosis facilitates crystal adhesion to cell surface, largely, which is a key step in urolithiasis $[17,18]$. When the cells are damaged, they release a large amount of reactive oxygen species (ROS), which is some intermediate metabolite of oxygen or the derivative of oxygen; ROS has more oxidative capacity than oxygen. Under normal conditions, the ROS level is very low and does not cause harm. The generation and removal of reactive oxygen in cells is in a dynamic equilibrium state. Once this balance is broken, the damage can be done, causing oxidative stress damage to the cells and death of the cells in severe cases [19], the basal membrane of the damaged renal tubular epithelial cells was exposed, making it easier for more crystals to adhere to the renal tubular epithelial cells, resulting in calcium deposition. Fetuin-A, also known as a2-Heremans-Schmid glycoprotein (AHSG), possesses potent calcification-inhibitory activity [20]. It had been proved that patients with urolithiasis had lower urine FetuinA levels compared with the control [21].

To sum up, since the Fetuin-A, hydroxyapatite, macrophages, and cell apoptosis are associated with the formation of urinary stones, so we venture to guess that whether there is some kind of connection among them. To test our hypothesis, we developed an in vitro system by co-culturing HK-2 cells with different concentration of HAP and/or macrophage cells to close to the internal environment of urolithiasis as far as possible, this co-culture can make up for the information defect caused by the previous single-cell plant research, so as to make the body match the environment in vitro as far as possible. Therefore, we can better explore the role of macrophages-renal tubular epithelial cell-hydroxyapatite in RP formation, clarify the relationship between the various inflammatory factors related, and may provide a new idea for the mechanism of RP formation.

\section{Materials and methods}

\section{Cell culture}

HK-2 cells were purchased from China Center for Type Culture Collection and cultured in DMEM/F12 (Life Technologies $^{\mathrm{TM}}$ ) supplemented with 10\%FBS (Gibcol, from Life Technologies $\left.{ }^{\mathrm{TM}}\right), 100 \mathrm{U} / \mathrm{ml}$ penicillin and $100 \mathrm{mg} / \mathrm{ml}$ streptomycin in a humidified $5 \% \mathrm{CO}_{2}$ incubator at $37{ }^{\circ} \mathrm{C}$. We routinely seeded cells at a density of $5 \times 10^{4} / \mathrm{cm}^{2}$ in culture vessel (Corning, Life Technologies ${ }^{\mathrm{TM}}$ ). We changed medium every day and subcultured cells before forming confluent monolayers.

The human monocytic cell line U937 were obtained from China Center for Type Culture Collection and grown in RPMI 1640 BASIC (Life Technologies ${ }^{\mathrm{TM}}$ ) supplemented with $10 \%$ FBS. We transferred the cell suspension into a tube and centrifuged cells at 1000 r.p.m. $\times 5$ min. Thus, the cells were washed and suspended in RPMI1640 BASIC (Life Technologies $^{\mathrm{TM}}$ ) with $10 \%$ FBS for use. Then, cell density was adjusted to $1 \times 10^{6}$ cells $/ \mathrm{ml}$ in RPMI1640 BASIC containing $10 \% \mathrm{FBS}$, and the cells were distributed in the isolated upper compartments of a transwell system and incubated for 1 day in a humidified $5 \% \mathrm{CO}_{2}$ incubator at $37{ }^{\circ} \mathrm{C}$. We treated the cells with $80 \mathrm{ng} / \mathrm{ml}$ phorbol 12 -myristate 13-acetate (PMA, from Sigma-Aldrich) for $48 \mathrm{~h}$ at $37^{\circ} \mathrm{C}$ and named as $\mathrm{M} \varphi$ macrophage cells. Then, for M1 macrophage differentiation, the $M \varphi$ macrophage cells were stimulated by RPMI1640 BASIC with $500 \mathrm{ng} / \mathrm{ml}$ LPS (O55:B5, SigmaAldrich), and for $\mathrm{M} 2$ macrophage differentiation, the $\mathrm{M} \varphi$ macrophage cells were stimulated by RPMI1640 BASIC with $20 \mathrm{ng} / \mathrm{ml} \mathrm{IL-4} \mathrm{(SRP3093,} \mathrm{Sigma-Aldrich).}$ 


\section{Groups and co-culturing}

Six groups were established. The $\mathrm{H}$ group (controls) was only comprised of HK-2 cells. Co-culture groups included $\mathrm{H}+\mathrm{M}$ group (HK-2 cells co-cultured with macrophage cells), $\mathrm{H}+\mathrm{A}$ group [HK-2 cells co-cultured with HAP (677418, from Sigma-Aldrich)], and $\mathrm{H}+\mathrm{M}+\mathrm{A}$ group (HK-2 cells co-cultured with HAP and macrophage cells). We carried out co-culture in a new transwell system. First, we differentiated macrophage cells in the isolated upper compartments. We changed medium into DMEM/F12 without FBS before co-culturing. We seeded HK- 2 cells in the lower compartment, and replaced medium with FBS-free medium before co-culturing. Based on relative study [22], in the $\mathrm{H}+\mathrm{A}$ group and the $\mathrm{H}+\mathrm{M}+\mathrm{A}$ group, we, respectively, transferred HAP into the lower compartment with the concentration of 5 and $10 \mu \mathrm{g} / \mathrm{cm}^{2}$ (Fig. 1). After coculturing for 2,4 and $6 \mathrm{~h}$, we, respectively, investigate lactate dehydrogenase (LDH) level, reactive oxygen species (ROS) level, 4'-6-diamidino-2-phenylindole (DAPI) staining assay kit, Enzyme-linked immunosorbent assays (ELISA), Flow Cytometry, and Western Blotting. In addition, when testing the expression of CCL-2 in the medium, we added the $\mathrm{M}+\mathrm{A}$ group (macrophage cells co-cultured with HAP), we, respectively, transferred HAP into the lower compartment with the concentration of 5 and $10 \mu \mathrm{g} / \mathrm{cm}^{2}$ (Fig. 1).

\section{Lactate dehydrogenase (LDH)}

As an indication of cell injury, we measured LDH release from the HK-2 cells of all groups in the media. Media of all groups were aliquoted to 96-well plates; then, LDH activity was assayed by absorbance change at a wavelength of $450 \mathrm{~nm}$ on a Multiskan ${ }^{\mathrm{TM}}$ GO microplate reader (Thermo Scientific $^{\mathrm{TM}}$ ) with assay kit (Nanjing Jiancheng Bioengineering Institute, Nanjing, China).

\section{Flow cytometry}

To determine whether the reduced cell viability is related to apoptosis, flow cytometry analysis was further performed using an Annexin V-Fluorescein Isothiocyanate (FITC) Apoptosis Detection kit (BD Pharmingen, San Diego, CA, USA), according to the manufacturers protocol.

After being co-cultured for 2, 4, and $6 \mathrm{~h}$, the cells were then washed twice with PBS, centrifuged at $375 \times g$ for $5 \mathrm{~min}$, and resuspended in $500 \mu \mathrm{l}$ binding buffer. We added $5 \mu \mathrm{l}$ Annexin V-FITC and mixed into the cell suspension, followed by the addition of $5 \mu$ propidium iodide and subsequent mixing, and then incubated the reaction for 5-15 min in a dark room. Finally, we detected the early apoptotic cells by flow cytometry within $1 \mathrm{~h}$.
H group( control group )
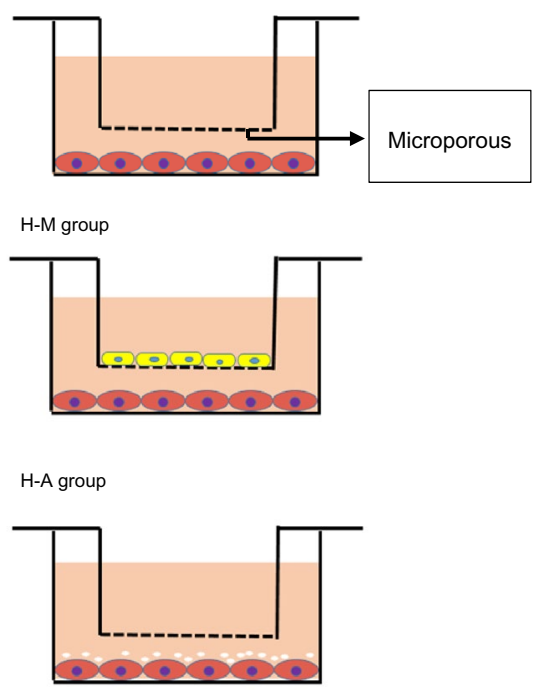

$\mathrm{M}+\mathrm{A}$ group
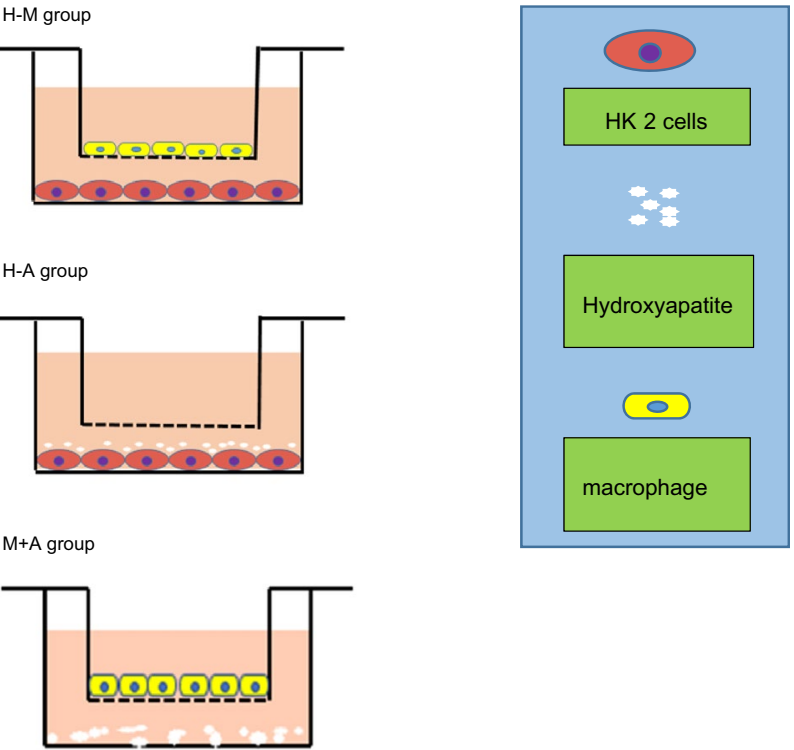

H-M-A group

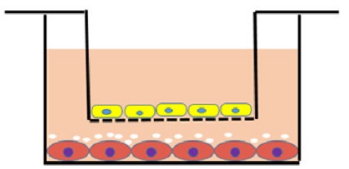

Fig. 1 In co-cultured system, three groups were established, including $\mathrm{H}$ (control) - $\mathrm{HK}-2$ cells cultivated independently of other types, $\mathrm{H}+\mathrm{M}-$ co-cultured $\mathrm{HK}-2$ cells and $\mathrm{M} 1$ macrophage cells, $\mathrm{H}+\mathrm{A}-$ co-cultured HK-2 cells and HAP, M+A-co-cultured M1 macrophage cells and $\mathrm{HAP}, \mathrm{H}+\mathrm{M}+\mathrm{A}-$ co-cultured $\mathrm{HK}-2$ cells, HAP and M1 macrophage cells. Microporous membranes separated upper and lower compartments

\section{Western blotting}

After co-culturing for 2,4 , and $6 \mathrm{~h}$, total protein was, respectively, extracted from cultured HK-2 cells only in $\mathrm{H}$, $\mathrm{H}+\mathrm{A}$ and $\mathrm{H}+\mathrm{M}+\mathrm{A}$ group using the RIPA Lysis Buffer (Beyotime) containing 2\% PMSF (Beyotime) according to the manufacturer's instructions, and then collected protein samples and subjected to western blotting performed essentially according to an established procedure [23]. The primary antibodies used were as follows: mouse anti-human GAPDH (1:10,000, ProteinTech, Chicago, IL, USA), mouse anti-human Fetuin-A, and Anti-Osteopontin (1:2000, Abcam, Cambridge, MA, USA), and BCL-2 (1:2000, D55G8) Rabbit mAb, BAX Antibody (1:2000). 
We performed quantifications by measuring band intensities using AlphaView and Image lab analysis software.

\section{4'-6-diamidino-2-phenylindole staining assay}

The apoptotic nuclei were detected using 4'-6-diamidino2-phenylindole (DAPI) assay kit (Solarbio Corporation, Beijing, China), which is a deoxyribonucleic acid-specific fluorescent dye, as previously described [24].

\section{Determination of reactive oxygen species (ROS) generation}

We measured ROS generation with the fluoroprobe, $2^{\prime}$, 7'-dichlorodihydrofluorescein diacetate (DCF-DA) (Solarbio Corporation, Beijing, China). After the cells were cocultured for 2,4 , and $6 \mathrm{~h}$, the cells were incubated with $5 \mu \mathrm{M}$ DCF-DA for $30 \mathrm{~min}$ at $37^{\circ} \mathrm{C}$, as previously described [25]. We obtained the images using a fluorescence microscope (Olympus Corporation, Tokyo, Japan).

\section{Cytokine measurement in culture medium}

We performed enzyme-linked immunosorbent assays to measure levels of CCL- 2 , TNF- $\alpha$, and TNF- $\beta$ (R\&D Systems; Minneapolis, MN, USA) produced in the supernatant of each culture dish.

\section{Statistical analysis}

One-way analysis of variance (ANOVA). We performed the statistical analyses using statistical software (GraphPad Software Inc., San Diego, CA, USA). We considered a $P<0.05$ as statistically significant.

\section{Results}

\section{The induction and qualification of M1 macrophage cells}

Based on the mentioned methods, we induced the U937 cells to M1 and M2 macrophage cells. As TNF- $\alpha$ is a typical M1-marker and TGF- $\beta$ is a typical M2-marker [26, 27], we detected, respectively, the expression of TNF- $\alpha$ and TGF- $\beta$ in the medium by ELISA to evaluate whether we successfully induced the M1 macrophage cells or not. Like Fig. 2 showed, TNF- $\alpha$ in the medium of M1 macrophage cells was higher than $\mathrm{M} \varphi$ and M2 (* $P<0.05)$, TGF- $\beta$ in the medium of M2 macrophage cells was higher than $\mathrm{M} \varphi$ and M1 ( $\left.{ }^{\#} P<0.05\right)$. These results demonstrated that we successfully induced the M1 macrophage cells (Fig. 2).

\section{The expression of CCL-2 in the medium}

At different co-culture time, CCL-2 in the medium was no statistically different between the $\mathrm{H}+\mathrm{M}$ group and the $\mathrm{H}$ group $(P>0.05)$. It demonstrated that the HK- 2 cells could not activate macrophage cells, although the HK-2 and U937 cells originated from different donors. In other words, due to the HK-2 cells and U937 cells came from different donors and HK-2 cells may have certain immunogenicity of macrophage cells, but this kind of immunogenicity was not enough to activate macrophages to come up with severe inflammation reaction, and the interference to our experimental results can be neglected.

The CCL-2 in the medium of $\mathrm{H}+\mathrm{A}$ and $\mathrm{H}+\mathrm{A} 2$ increased statistically compared with the control $(P<0.05)$. We can infer that HAP can activate the HK-2 cells to secrete a small amount of CCL-2. However, compared with $\mathrm{M}+\mathrm{A} 1$ and $\mathrm{H}+\mathrm{A} 1$ group in our observation window, we found that the CCL-2 was mainly from the macrophage cells. In addition, the concentration of HAP was higher and the stimulation time longer, the expression of CCL-2 increased, and the inflammation aggravated. If we co-cultured HK-2 cells with HAP and macrophage cells, the expression of CCL-2 can
Fig. 2 Expression of TNF- $\alpha$ and TGF- $\beta$ in the media. Each column represented the mean \pm the standard error of the mean. ${ }^{*} P<0.05$ vs. $\mathrm{M} \varphi .{ }^{\#} P<0.05$ vs. $\mathrm{M} \varphi$. The data were representative of at least three independent experiments
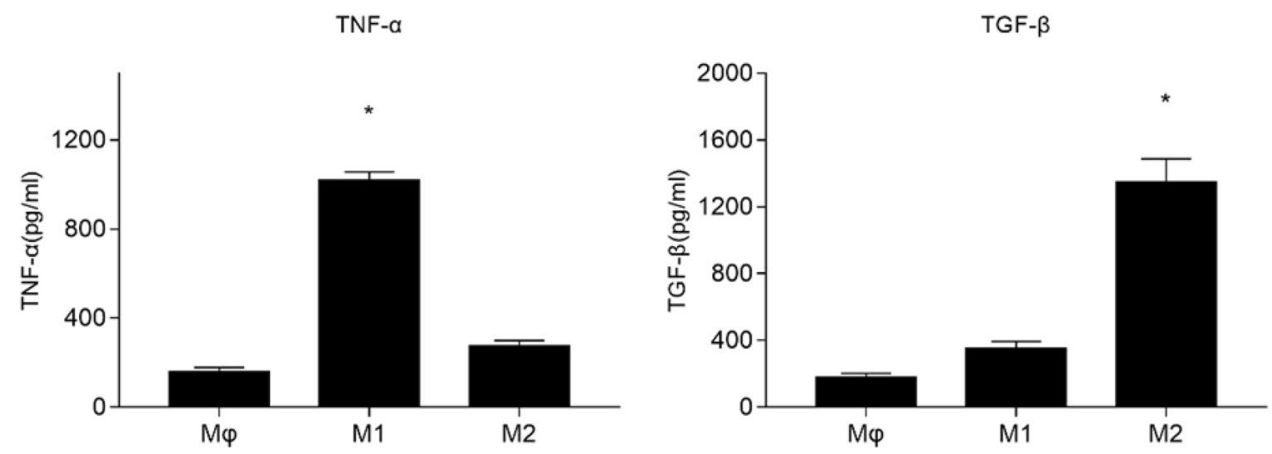
be even higher. For example, compared with $\mathrm{H}, \mathrm{H}+\mathrm{A} 1$ and $\mathrm{M}+\mathrm{A} 1$ group, the CCL-2 of $\mathrm{H}+\mathrm{M}+\mathrm{A} 1$ group increased statistically $(P<0.05)$. Moreover, the CCL-2 of $\mathrm{H}+\mathrm{M}+\mathrm{A} 2$ group went up statistically in a time-dependent manner compared with the $\mathrm{H}+\mathrm{M}+\mathrm{A} 1$ group $(P<0.05)$ (Fig. 3).

The above results show that the CCL-2 are mainly from the M1 macrophage cells, although HAP also can stimulate the HK-2 cells to produce a certain amount of CCL-2. HAP could induce HK-2 cells to inflammation in a timedependent manner. In addition, the M1 macrophage cells can aggravate this inflammation.

\section{The expression of OPN in HK-2 cells}

At $2 \mathrm{~h}$, the osteopontin (OPN) protein in HK-2 cells increased significantly in the $\mathrm{H}+\mathrm{A} 1, \mathrm{H}+\mathrm{A} 2, \mathrm{H}+\mathrm{M}+\mathrm{A} 1$, and $\mathrm{H}+\mathrm{M}+\mathrm{A} 2$ group $(P<0.05$ vs. $\mathrm{H}$ group, $2 \mathrm{~h})$. At 4 and $6 \mathrm{~h}$, there were significantly increase from the $\mathrm{H}+\mathrm{A} 1$ group to the $\mathrm{H}+\mathrm{M}+\mathrm{A} 2$ group $(P<0.05)$. These results can fully prove that the expression of OPN in HK-2 cells increased in a dose-and time-dependent manner after the stimulation of HAP; meanwhile, the M1 macrophage cells can lead the OPN in HK-2 cells to increase much more. In our observation window, the expression of $\mathrm{OPN}$ in $\mathrm{H}+\mathrm{M}+\mathrm{A} 2$ group was the highest (Fig. 4).

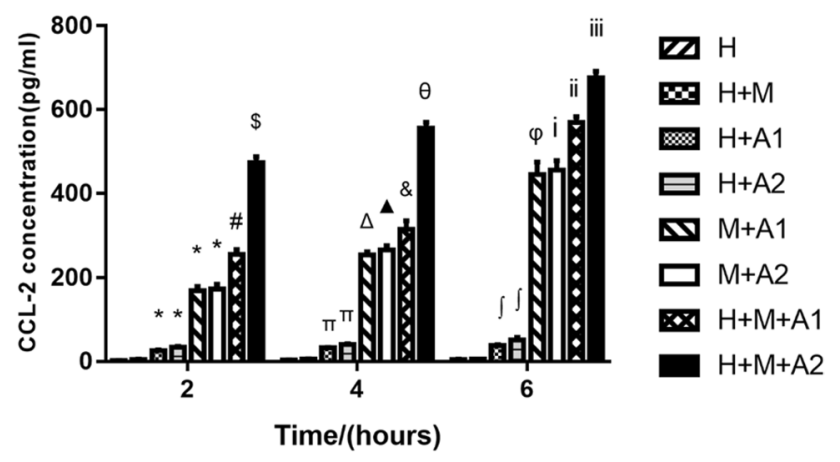

Fig. 3 Expression of CCL-2 in the medium of the $\mathrm{H}, \mathrm{H}+\mathrm{M}, \mathrm{H}+\mathrm{A} 1$, $\mathrm{H}+\mathrm{A} 2, \mathrm{M}+\mathrm{A} 1, \mathrm{M}+\mathrm{A} 2, \mathrm{H}+\mathrm{M}+\mathrm{A} 1$, and $\mathrm{H}+\mathrm{M}+\mathrm{A} 2$ groups at 2,4 , and $6 \mathrm{~h}$, respectively. Each column represented the mean \pm the standard error of the mean. ${ }^{*} P<0.05$ vs. $\mathrm{H}$ group $(2 \mathrm{~h}) .{ }^{\#} P<0.05$ vs. $\mathrm{H}$ group $(2 \mathrm{~h}), \mathrm{H}+\mathrm{A} 1$ group $(2 \mathrm{~h})$ and $\mathrm{M}+\mathrm{A} 1$ group $(2 \mathrm{~h})$. ${ }^{\$} P<0.05$ vs. $\mathrm{H}$ group ( $\left.\mathrm{h}\right), \mathrm{H}+\mathrm{A} 2$ group $(2 \mathrm{~h}), \mathrm{M}+\mathrm{A} 2$ group $(2 \mathrm{~h})$, $\mathrm{H}+\mathrm{M}+\mathrm{A} 1$ group $(2 \mathrm{~h}) . \Delta P<0.05$ vs. $\mathrm{H}$ group $(4 \mathrm{~h}), \mathrm{M}+\mathrm{A} 1$ group $(2 \mathrm{~h}) .{ }^{\Delta} P<0.05$ vs. $\mathrm{H}$ group $(4 \mathrm{~h}), \mathrm{M}+\mathrm{A} 2$ group $(2 \mathrm{~h}) .{ }^{\&} P<0.05$ vs. $\mathrm{H}$ group $(4 \mathrm{~h}), \mathrm{H}+\mathrm{A} 1$ group $(4 \mathrm{~h}), \mathrm{M}+\mathrm{A} 1$ group $(4 \mathrm{~h})$ and $\mathrm{H}+\mathrm{M}+\mathrm{A} 1$ group $(2 \mathrm{~h}) . \theta P<0.05$ vs. $\mathrm{H}$ group $(4 \mathrm{~h}), \mathrm{H}+\mathrm{A} 2$ group (4 h), M+A2 group (4 h), $\mathrm{H}+\mathrm{M}+\mathrm{A} 2$ group (2 h) and $\mathrm{H}+\mathrm{M}+\mathrm{A} 1$ group $(4 \mathrm{~h}) .{ }^{\varphi} P<0.05$ vs. $\mathrm{H}$ group $(6 \mathrm{~h}), \mathrm{M}+\mathrm{A} 1$ group $(2 \mathrm{~h})$, $\mathrm{M}+\mathrm{A} 1$ group (4 h). ${ }^{\mathrm{i}} \mathrm{P}<0.05$ vs. $\mathrm{H}$ group $(6 \mathrm{~h}), \mathrm{M}+\mathrm{A} 2$ group $(2 \mathrm{~h})$ and $\mathrm{M}+\mathrm{A} 2$ group $(4 \mathrm{~h}) .{ }^{\mathrm{ii}} \mathrm{P}<0.05$ vs. $\mathrm{H}$ group $(6 \mathrm{~h}), \mathrm{H}+\mathrm{A} 1$ group $(6 \mathrm{~h}), \mathrm{M}+\mathrm{A} 1$ group $(6 \mathrm{~h}), \mathrm{H}+\mathrm{M}+\mathrm{A} 1$ group $(2 \mathrm{~h})$, and $\mathrm{H}+\mathrm{M}+\mathrm{A} 1$ group (4 h). ${ }^{\text {iii }} \mathrm{P}<0.05$ vs. $\mathrm{H}$ group $(6 \mathrm{~h}), \mathrm{H}+\mathrm{A} 2$ group $(6 \mathrm{~h}), \mathrm{M}+\mathrm{A} 2$ group (6 h), H+M+A1 group (6 h), H+M+A2 group (2h), and $\mathrm{H}+\mathrm{M}+\mathrm{A} 2$ group $(4 \mathrm{~h})$. The data were representative of at least three independent experiments

\begin{tabular}{|l|c|c|c|c|c|c|}
\hline & $\mathrm{H}$ & $\begin{array}{c}\mathrm{H}+ \\
\mathrm{M}\end{array}$ & $\begin{array}{c}\mathrm{H}+\mathrm{A} \\
1\end{array}$ & $\begin{array}{c}\mathrm{H}+\mathrm{A} \\
2\end{array}$ & $\begin{array}{c}\mathrm{H}+\mathrm{M} \\
+\mathrm{A} 1\end{array}$ & $\begin{array}{c}\mathrm{H}+ \\
\mathrm{M}+ \\
\mathrm{A} 2\end{array}$ \\
\hline $\mathrm{OPN}(2 \mathrm{H})$ & & & & \\
\hline OPN(4H) & & & \\
\hline OPN(6H) & & & \\
\hline GAPDH & &
\end{tabular}

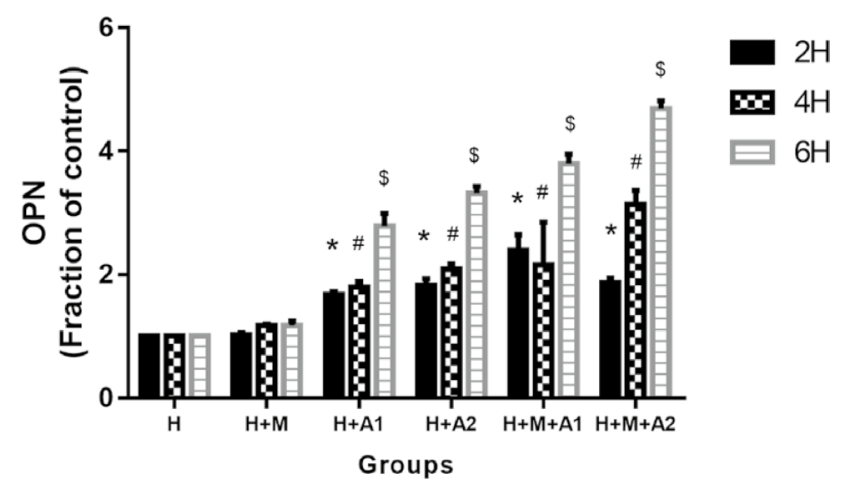

Fig. 4 Expression of OPN in HK-2 cells of all groups at 2, 4, and $6 \mathrm{~h}$, respectively. Each column represented the mean \pm the standard error of the mean. ${ }^{*} P<0.05$ vs. H group, 2 h. ${ }^{\#} P<0.05$ vs. $\mathrm{H}$ group, $4 \mathrm{~h}$. ${ }^{\$} P<0.05$ vs. $\mathrm{H}$ group, $6 \mathrm{~h}$. The data were representative of at least three independent experiments

\section{Reactive oxygen species generation (ROS)}

We detected the generation of ROS using the ROS-sensitive fluorescent dye, DCF-DA. The intensity of DCF-DA fluorescence increased in a dose-and time-dependent manner $(P<0.05)$. In our observation window, the intensity of DCF-DA in $\mathrm{H}+\mathrm{M}+\mathrm{A} 2$ group at $6 \mathrm{~h}$ incubation time achieved the highest (Fig. 5).

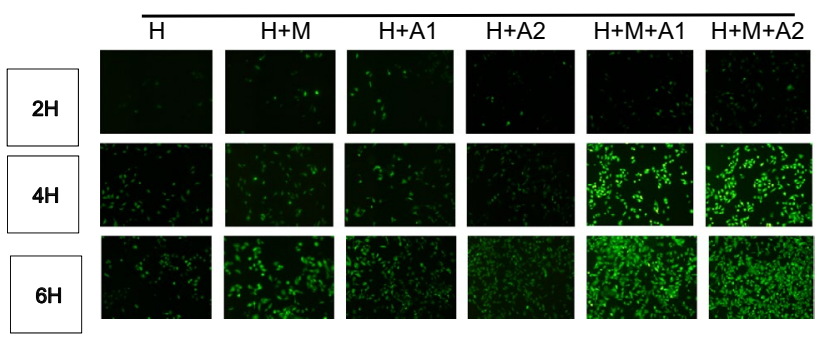

Fig. 5 Original magnification, $\times 10$. Scale bar $50 \mu \mathrm{m}$ 


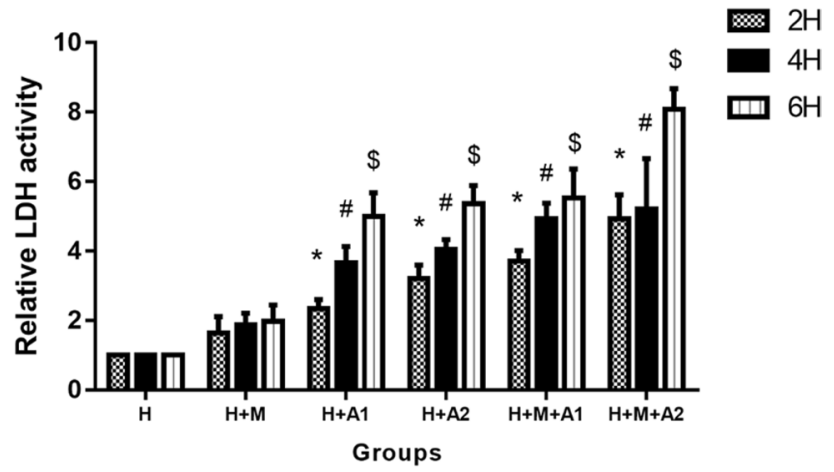

Fig. 6 LDH level in the media of all groups for 2, 4, and $6 \mathrm{~h}$. Each column represented the mean \pm the standard error of the mean. ${ }^{*} P<0.05$ vs. control at $2 \mathrm{~h}$. ${ }^{\#} P<0.05$ vs. control at $4 \mathrm{~h},{ }^{\$} P<0.05$ vs. control at $6 \mathrm{~h}$. The data were representative of at least three independent experiments

\section{Lactate dehydrogenase (LDH) release}

Figure 6 shows LDH release level in the media of all groups. There was a time- and concentration-dependent increase in LDH release by HK- 2 cells. At 2 and $4 \mathrm{~h}$ incubation periods, LDH release significantly rose in all experimental groups except $\mathrm{H}+\mathrm{M}$ group $(P<0.05)$. At $6 \mathrm{~h}$ incubation periods, LDH release increased more heavily than other time, and the difference between all experimental groups (expect $\mathrm{H}+\mathrm{M}$ group) and the control were statistically significant $(P<0.05)$.

\section{BAX/BCL-2}

We assessed the apoptosis in HK-2 cells of all groups at 2, 4, and 6 h (Fig. 7). Hydroxyapatite (HAP) and macrophage cells increased BAX expression while inhibiting that of BCL-2 in a time-and concentration-dependent manner, which resulted in an increased BAX/BCL-2 ratio in the HK-2 cells. Only did the $\mathrm{H}+\mathrm{M}+\mathrm{A} 2$ group increase significantly compared with the control at $2 \mathrm{~h}$ incubation time $(P<0.05)$. At $4 \mathrm{~h}$, there was significant difference in the $\mathrm{H}+\mathrm{M}+\mathrm{A} 1$ and $\mathrm{H}+\mathrm{M}+\mathrm{A} 2$ group compared with the control $(P<0.05)$. At $6 \mathrm{~h}$, compared with the control, there was significantly increasing of $\mathrm{BAX} / \mathrm{BCL}-2$ ratio in all experimental groups except the $\mathrm{H}+\mathrm{M}$ group $(P<0.05)$. As BAX is the promoting apoptosis protein, while BCL-2 is the suppressing apoptosis protein, the higher BAX/BCL-2 ratio means the more serious apoptosis. Our research results revealed that HAP could lead HK-2 cells to apoptosis in a time- and dose-independent manner; furthermore, the apoptosis can be aggravated by the M1 macrophage cells. In our observation window, the ratio of BAX/BCL-2 in $\mathrm{H}+\mathrm{M}+\mathrm{A} 2$ group at $6 \mathrm{~h}$ incubation time achieved the highest that meant the most serious apoptosis.

\begin{tabular}{|c|c|c|c|c|c|c|}
\hline & $\mathrm{H}$ & $\begin{array}{l}\mathrm{H}+ \\
\mathrm{M} \\
\end{array}$ & $\begin{array}{c}\mathrm{H}+\mathrm{A} \\
1 \\
\end{array}$ & $\begin{array}{c}\mathrm{H}+\mathrm{A} \\
2 \\
\end{array}$ & $\begin{array}{l}\mathrm{H}+\mathrm{M} \\
+\mathrm{A} 1 \\
\end{array}$ & $\begin{array}{c}\mathrm{H}+\mathrm{M}+ \\
\mathrm{A} 2 \\
\end{array}$ \\
\hline $\operatorname{Bax}(2 \mathrm{H})$ & \multicolumn{6}{|c|}{$+-m-\infty$} \\
\hline $\mathrm{Bcl}-2(2 \mathrm{H})$ & & & & & & \\
\hline $\operatorname{Bax}(4 \mathrm{H})$ & 20 & $-\infty$ & 6. 15 & $5=$ & nisio & 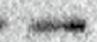 \\
\hline $\mathrm{BCl}-2(4 \mathrm{H})$ & $\longrightarrow$ & $\longrightarrow$ & - & $=$ & 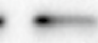 & $\longrightarrow$ \\
\hline $\operatorname{Bax}(6 \mathrm{H})$ & - & - & - & - & 一 & - \\
\hline $\mathrm{BCl}-2(6 \mathrm{H})$ & - & - & - & $\cdots$ & - & \\
\hline GAPDH & $\longrightarrow$ & $\longrightarrow$ & $=$ & - & $\longrightarrow$ & $\longrightarrow$ \\
\hline
\end{tabular}

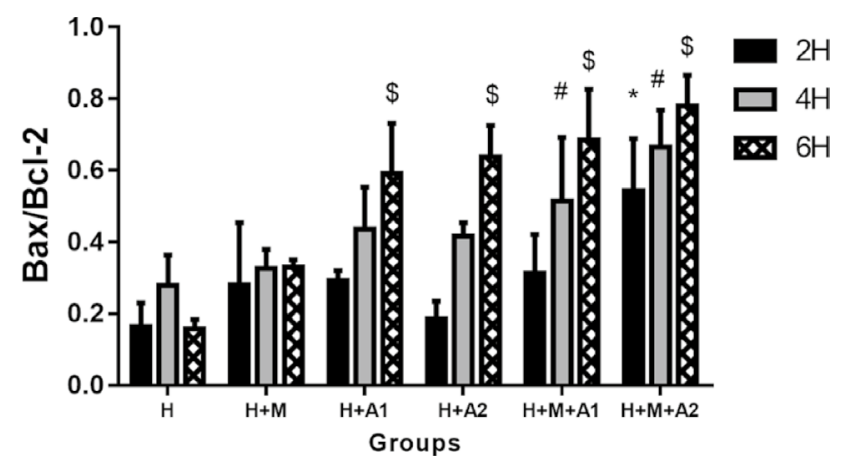

Fig. 7 BAX/BCL-2 ratio in HK-2 cells of all groups at 2, 4, and $6 \mathrm{~h}$, respectively. Each column represented the mean \pm the standard error of the mean. ${ }^{\#} P<0.05$ vs. H group, 4 h. ${ }^{\$} P<0.05$ vs. H group, $6 \mathrm{~h}$. The data were representative of at least three independent experiments

\section{Flow cytometry}

The apoptotic rate in our model increased in a dose- and time-dependent manner. From Fig. 8a-f, we find a small rise of apoptosis in our experimental groups at $2 \mathrm{~h} \mathrm{co-}$ culture time. When came to the $4 \mathrm{~h}$ incubation time, apoptosis rate of HK-2 cells in experimental groups increased a little more clearly than $2 \mathrm{~h}$, such as the apoptosis in $\mathrm{H}+\mathrm{M}+\mathrm{A} 2$ group had got $6.87 \%$. When co-culturing for $6 \mathrm{~h}$, the apoptosis of HK-2 cells became much more significantly than ever. Take Fig. $8 \mathrm{~m}, \mathrm{n}, \mathrm{p}$ for example, HAP can cause apoptosis of HK-2 cells, and the macrophage cells can exacerbate the HAP-induced apoptosis of HK-2 cells. Moreover, the apoptosis rate of $\mathrm{H}+\mathrm{M}+\mathrm{A} 2$ group got the highest percentage of $21.33 \%$, which provided further proof of our BAX/BCL-2 results in the western blotting analysis above. 

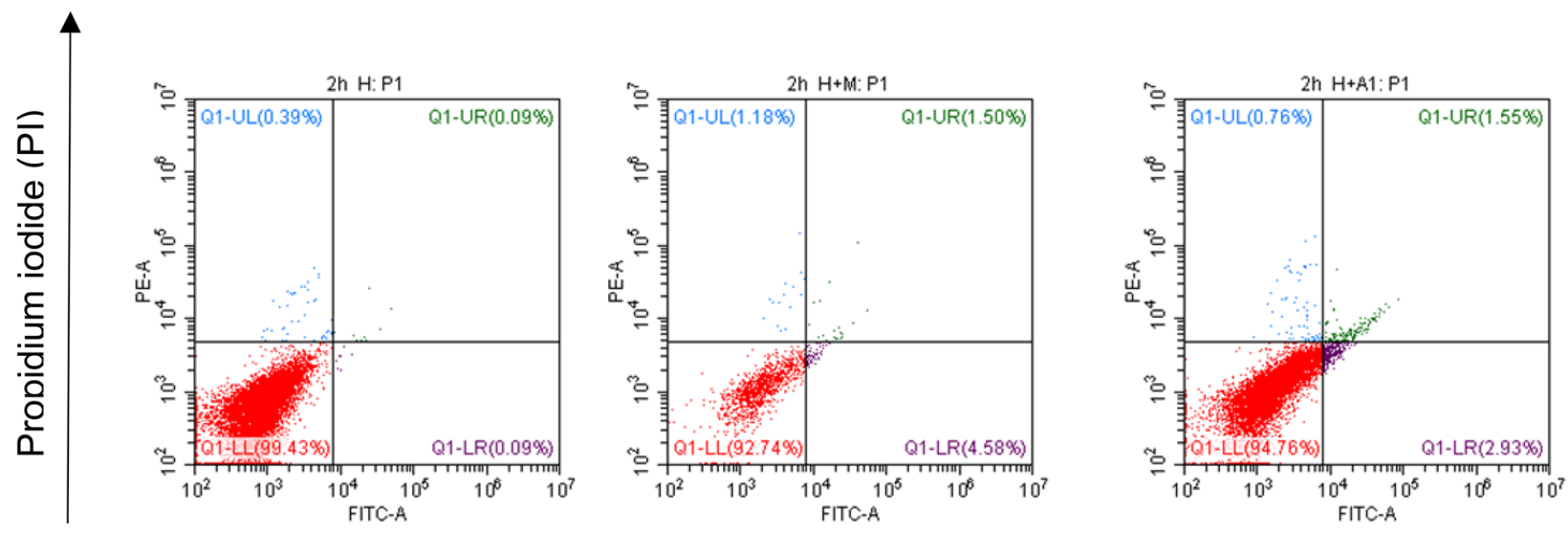

\section{Annexin V/FITC}

a

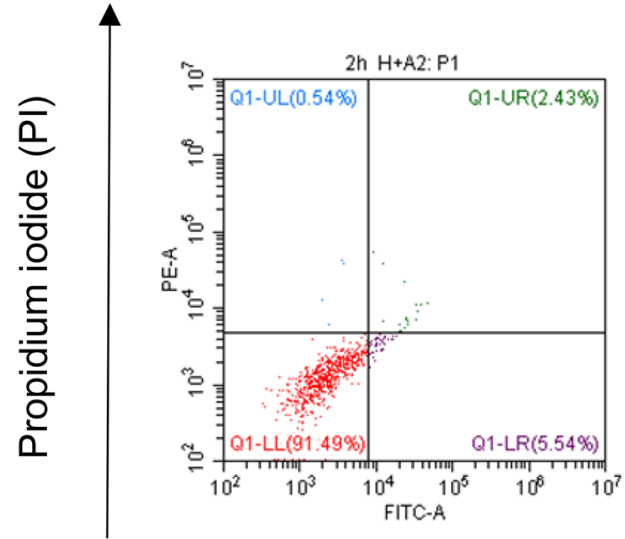

b

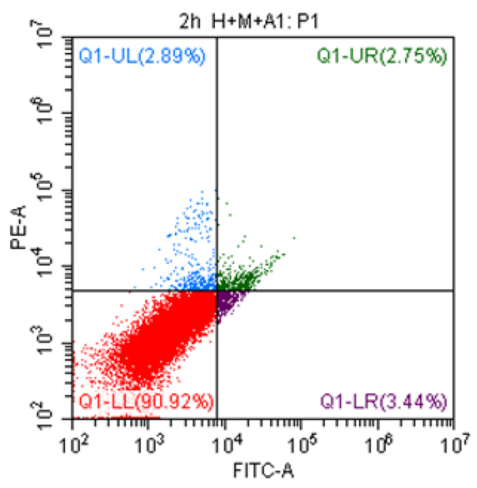

C

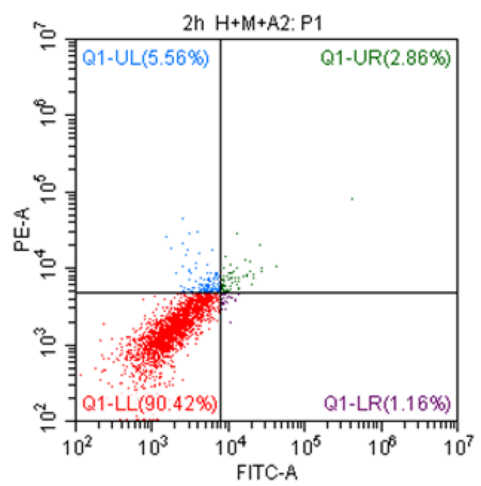

Annexin V/FITC

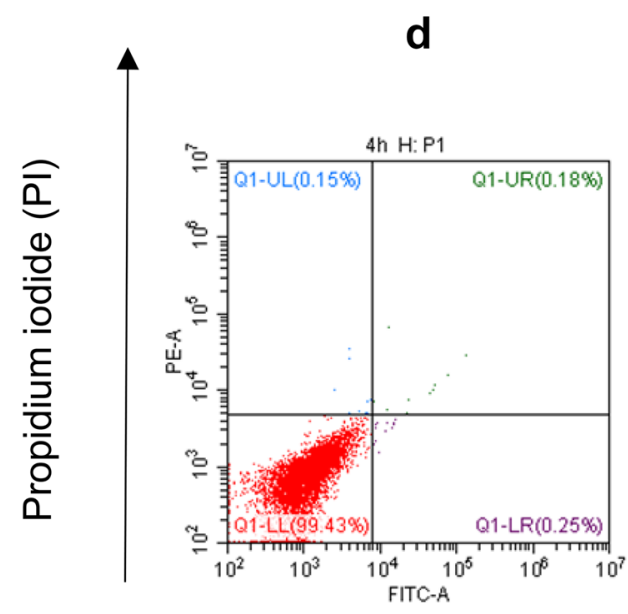

g e

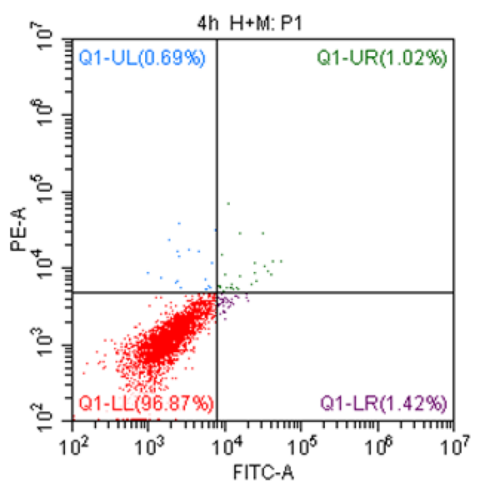

\section{Annexin V/FITC}

\section{$\mathbf{h}$}
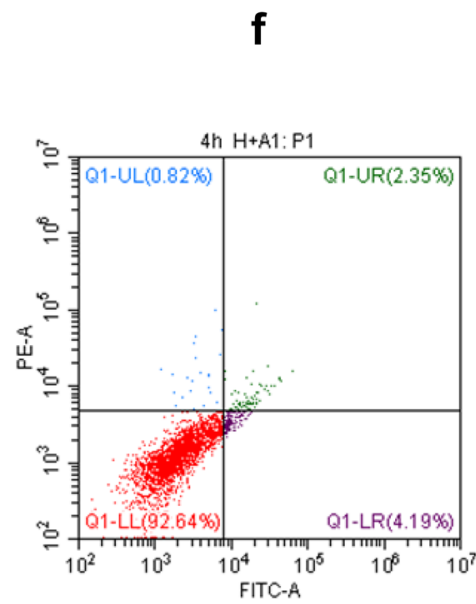

\section{i}

Fig. 8 FITC-conjugated annexin V proteins and PI staining. After co-culturing with HAP and/or macrophage cells, HK-2 cells exhibited a significant progressive increase in annexin $\mathrm{V}^{+} / \mathrm{PI}^{+}$staining 

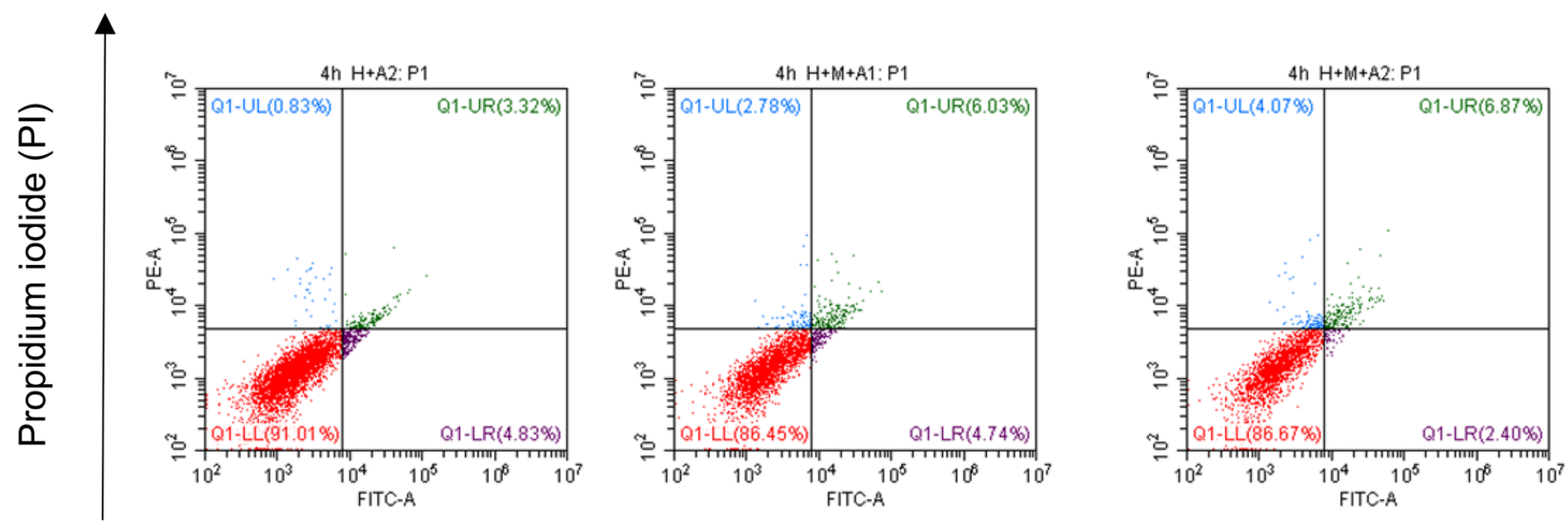

Annexin V/FITC

j

k
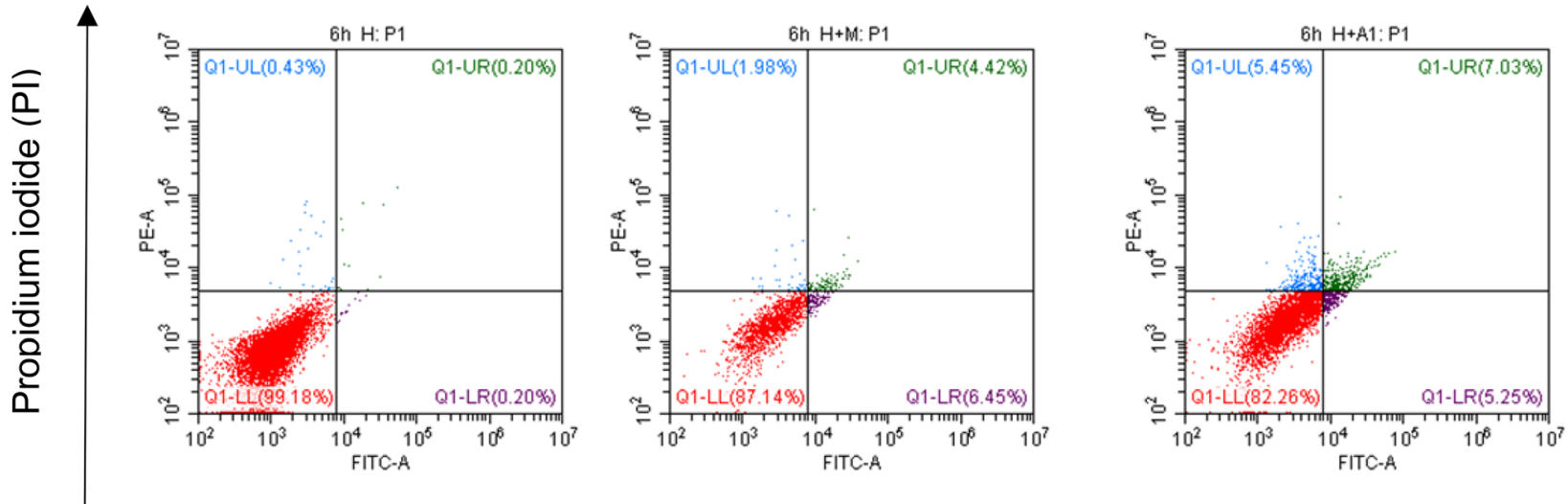

Annexin V/FITC
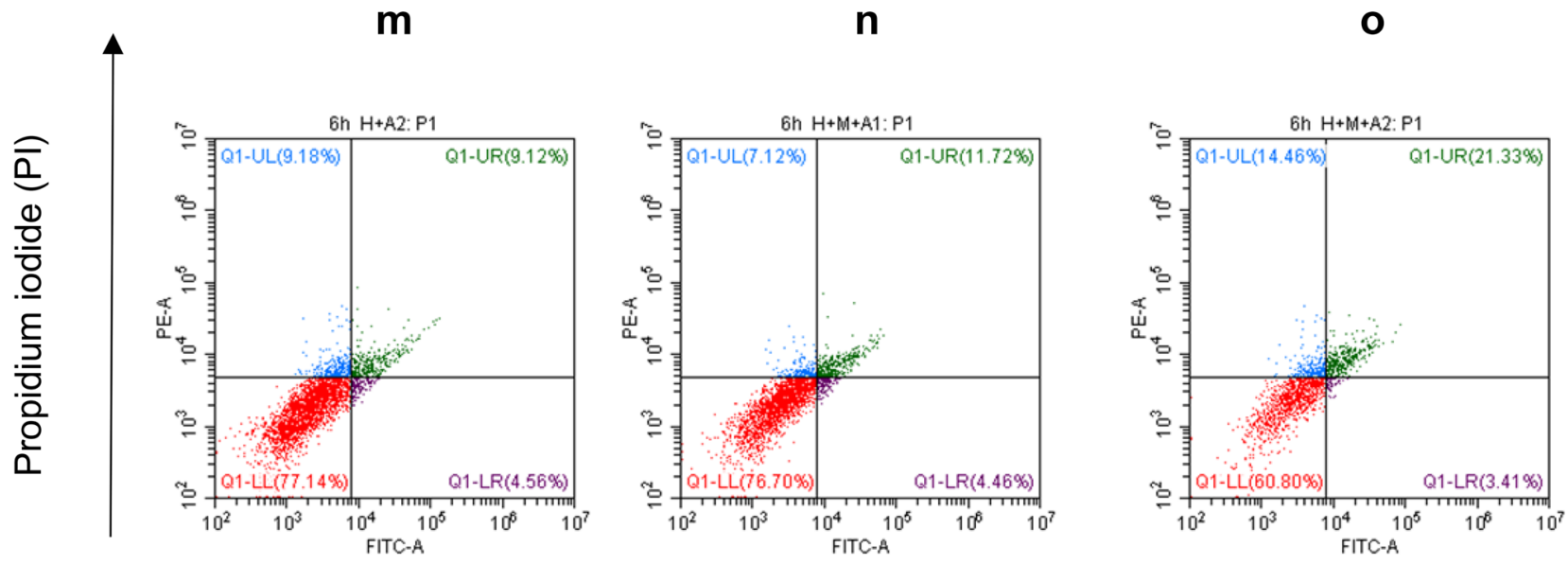

Annexin V/FITC

p

q

Fig. 8 (continued) 


\section{4'-6-diamidino-2-phenylindole (DAPI) staining assay}

After co-culturing for $6 \mathrm{~h}$, with the stimulation of macrophages and the increase of the concentration of HAP, apoptosis degree of each group aggravates gradually; moreover, the apoptosis degree of $\mathrm{H}+\mathrm{M}+\mathrm{A} 2$ group is most serious (Fig. 9).

\section{The expression of Fetuin-A}

At 2 and $4 \mathrm{~h}$ incubation time, Fetuin-A decreased softly and a significant difference was observed at $\mathrm{H}+\mathrm{A} 2$,
$\mathrm{H}+\mathrm{M}+\mathrm{A} 1$, and $\mathrm{H}+\mathrm{M}+\mathrm{A} 2$ group $(P<0.05)$. When coculturing for $6 \mathrm{~h}$, more drastic decline of Fetuin-A in HK-2 cells had been found. Especially the expression of Fetuin$\mathrm{A}$ in $\mathrm{H}+\mathrm{M}+\mathrm{A} 2$ group touched the bottom $(P<0.05)$ (Fig. 10). It declares that Fetuin-A in HK-2 cells decreases in a time- and HAP dose-dependent manner after HK-2 cells co-cultured with HAP, at the same time under the influence of macrophage cells, Fetuin-A in HK-2 cells drop even more.
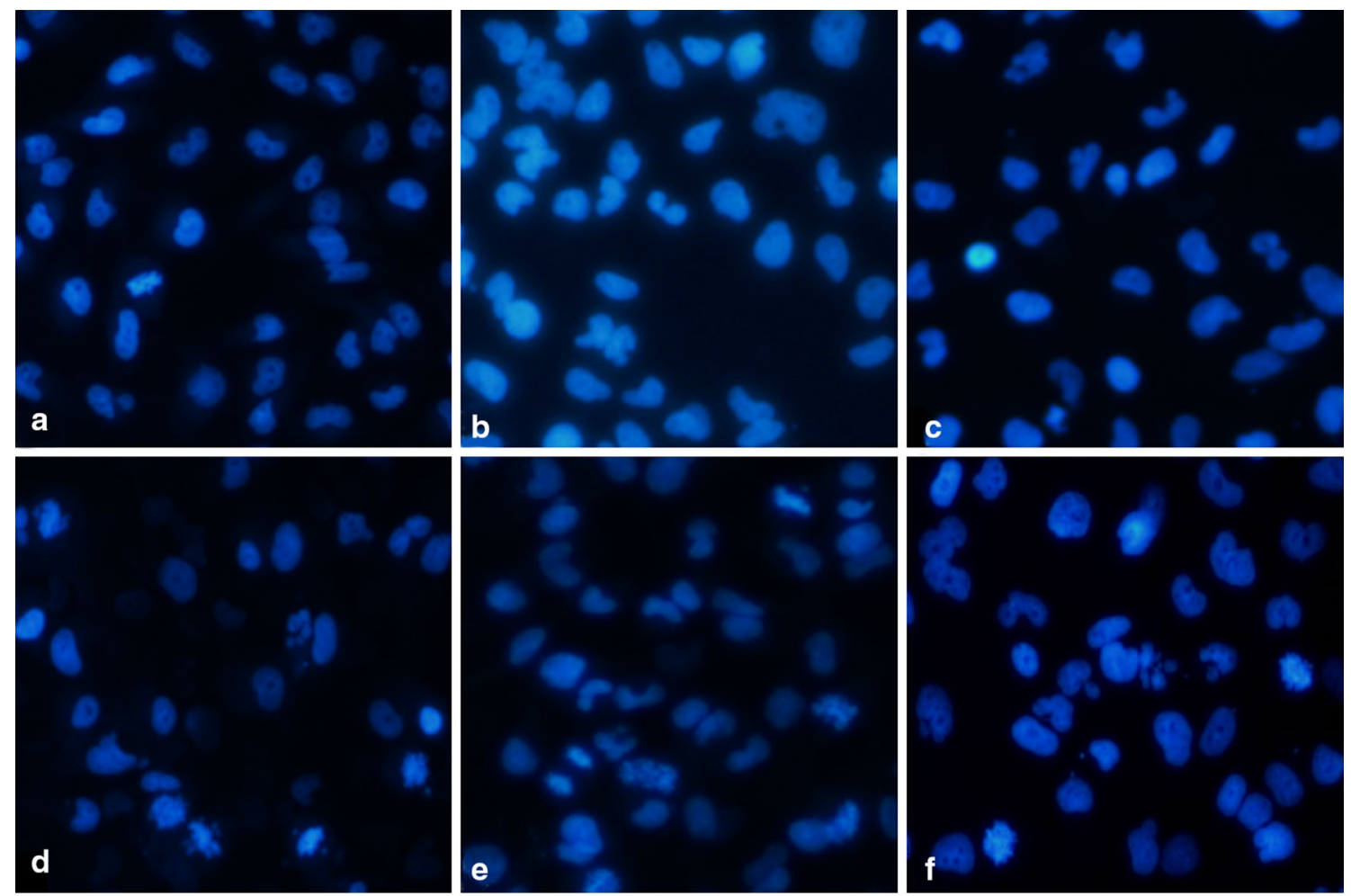

\begin{tabular}{|c|c|c|c|c|c|c|}
\hline & $\mathrm{H}$ & $\begin{array}{c}\mathrm{H}+ \\
\mathrm{M}\end{array}$ & $\begin{array}{c}\mathrm{H}+ \\
\mathrm{H}+\mathrm{A}\end{array}$ & $\begin{array}{c}\mathrm{H}+ \\
\mathrm{M}+\end{array}$ & $\begin{array}{c}\mathrm{H}+ \\
\mathrm{M}+ \\
\mathrm{A} 2\end{array}$ \\
\hline Fetuin-A(2H) & & & & \\
\hline Fetuin-A (4H) & - \\
\hline Fetuin-A (6H) & - \\
\hline GAPDH & & \\
\hline
\end{tabular}

Fig. 9 Original magnification, $\times 20$. Scale bar $20 \mu \mathrm{m}$. Note: $\mathrm{a}, \mathrm{b}, \mathrm{c}, \mathrm{d}, \mathrm{e}, \mathrm{f}$ represent $\mathrm{H}$ group, $\mathrm{H}+\mathrm{M}$ group, $\mathrm{H}+\mathrm{A} 1$ group, $\mathrm{H}+\mathrm{A} 2$ group, $\mathrm{H}+\mathrm{M}+\mathrm{A} 1$ group, and $\mathrm{H}+\mathrm{M}+\mathrm{A} 2$ group 


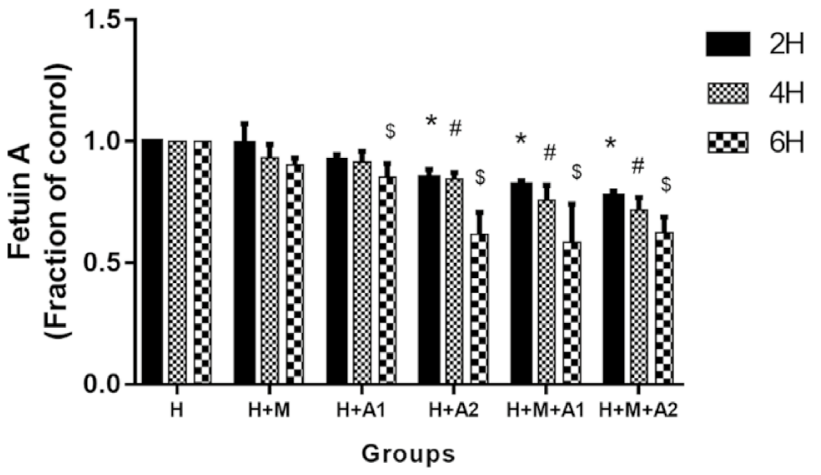

Fig. 10 Expression of Fetuin-A in HK-2 cells of all groups at 2, 4, and $6 \mathrm{~h}$, respectively. Each column represented the mean \pm the standard error of the mean. ${ }^{*} P<0.05$ vs. control at $2 \mathrm{~h},{ }^{\#} P<0.05$ vs. control at $4 \mathrm{~h},{ }^{\$} P<0.05 \mathrm{vs}$. control at $6 \mathrm{~h}$. The data were representative of at least three independent experiments

\section{Discussion}

Calcium oxalate crystals are a common component of urolithiasis; hydroxyapatite crystal is an important reason for the precipitation and condensation of calcium oxalate in the surface of renal papilla. As most of idiopathic calcium oxalate stone in the renal papilla adhesion area, Randall's plaques (RP) located in the pulp loops descending thin section of the basement membrane. RP is thought to be nuclei for the formation of future stones, because RP is hypothesized to play a role in idiopathic calcium oxalate nephrolithiasis by eroding into the urinary space and acting as a scaffold for mineralization with calcium oxalate $[7,8,10$, 28]. RP's main ingredient is apatite, which also includes calcium and magnesium phosphate [10]. Using high-resolution CT, Evan, A. P. and associates' study [29] display that stones have grown over Randall's plaque. What is more, Verrier, $\mathrm{C}$, et al. recently reveal that RP contain various calcium and magnesium phosphates as well as apatite [10]. Therefore, we speculated that apatite has played a very important role in the development of urolithiasis.

Macrophage cells are the key cells that mediate innate and adaptive immunity. Macrophage cells can aggravate the inflammation, and the inflammation can exacerbate the formation of kidney stones [30]. Ruud de Water [11] investigates that macrophages and multinucleated giant cells are the major cells that encapsulate the interstitial crystals in both rat and humans. Eventually, M1 macrophage cells are thought to be pro-inflammatory [31]. Meanwhile, the phagocytosis of macrophages also cannot be ignored. In the animal models of calcium oxalate, Okada [14] found oxalic acid induced crystals formed in the tube cavity and then reached the interstitium, which disappeared in a few weeks. Ultrastructural analysis of kidneys shows that mononuclear macrophages are involved in the process. After calcium oxalate crystal-induced renal tubular epithelial cells to injury, the macrophages came to engulf and digest crystals with osteopontin, CD44, and fiber connection proteins mediating.

On one hand, macrophages may be transferred to the mesenchymal by swallowing $\mathrm{CaO}_{x}$ crystals [32] in the lumen to start the process of calcification of the renal nipple. During the inflammatory response of the crystalline macrophage, many inflammatory factors are secreted, causing chronic injury to the tissue and promoting the fibrosis of the kidney, and finally form the RP. On the other hand, after swallowing the $\mathrm{CaO}_{x}$ crystals, the macrophages induce the differentiation of epithelial cells into osteoblasts, which can provide apatite for the formation of RP [33]. The basic structure of Randall spot was formed by the deposition of renal papillary fibrosis and apatite. As a result, macrophages plays very an important role in regulation of RP-mediated renal calcium oxalate stone formation. It is not difficult to infer that there is an intertwined relationship between macrophage cells and urolithiasis.

Co-culture means two different kinds of cells culture together. At present, most co-cultured technique applied in bone cells and nerve cells. Cell co-culture system mainly through two ways: one is the direct co-culture system, namely two or more than two kinds of cells simultaneously or, respectively, inoculated in the same hole, different kinds of cells contact directly. The other one is indirectly co-culture system. The two or more than two kinds of cells were inoculated on different carrier, and then put the two carrier in the same culture. It can make different kinds of cells share the same culture system without direct contact. The advantage of cell co-culture techniques is that it can establish a co-culture system more like the body environment, making the internal environment consistent with external environment as far as possible, so that different kinds of cells are able to communicate and support with each other [12, 34-36]. Therefore, we co-culture HK-2 cells with HAP and/ or macrophage cells; it can make up for the defects caused by study of usual single cells lines. Using this method of in vitro co-culture to explore the effects of HAP and macrophage cells to the expression of inflammatory factors and apoptosis in HK-2 cells of vitro co-cultured system, and how the macrophage cells regulate the influencing process.

As a negatively charged phosphorylated glycoprotein, OPN expressed in bone tissue, and expressed in the kidney, arterial vascular smooth muscle cell, urogenital tract, gallbladder, and other tissues. OPN showed a significant increase in renal expression levels in renal calculi rats [37], Langdon, A and Grohe, B investigated the interaction of OPN proteins and COM crystals by scanning electron microscopy and confocal microscopy, and found that the key control factor leading to the formation of stones was OPN [38]. By immunohistochemical method and transmission electron microscopy, Taguchi, K, and others found: OPN in 
RP expressed higher than the parts of renal tubular epithelial cells that do not contain RP [39]. These results revealed that OPN, as an important multi-functional protein, is associated so much with urolithiasis, the association is particularly prominent in OPN-mediated calcium oxalate crystals' adhesion, deposition in the renal tubular epithelial cells.

However, it is controversial whether OPN promoted or inhibited the formation of stone. On one hand, Thurgood LA and other experiments in vitro found that OPN could inhibit the growth of COD in urine and adhere to renal epithelial cells, thereby inhibiting the formation of urolithiasis [40]. On the other hand, Hirose et al. found that in the early stages of stones when calcium oxalate crystals caused the damage of renal tubule epithelial cells, the adhesion of OPN could induce the formation of heterogeneous nucleation of stone crystals [41].

Based on the close correlation between OPN and urolithiasis, we also examined the expression of OPN in renal tubule epithelial cells at this study. In this study, we found that after the stimulation of HAP, the expression of OPN in HK-2 cells increased in a time- and dose-dependent manner, and macrophage cells can aggravate the increase of OPN in HK-2 cells. In our observation window, the $\mathrm{H}+\mathrm{M}+\mathrm{A} 2$ group show the highest OPN expression after $6 \mathrm{~h}$ co-culture. Our experimental results (shown in Fig. 4) are consistent with these findings $[12,41-45]$. Therefore, we think that the increase of CCL-2 in culture medium and the up-regulation of OPN in renal tubular epithelial cells can cause a strong chemotactic effect on macrophages, aggravate inflammation [42-44], and exacerbate the process of crystal adhesion [12, 45]. In addition, the up-regulation of OPN also increases the heterogeneity of crystals and promotes the formation of stones, OPN combines with calcium phosphate to act as a matrix for stones, these matrix proteins also play a role in stopping to dissolve the calcium phosphate and inhibiting the accumulation and growth of crystals, and provide a form of aggregation and adhesion for free calcium ions in urine, therefore, oxalate or oxalate ions gradually formed nucleation on its surface and eventually formed calcium oxalate kidney stone [41].

As reported previously, renal epithelial cell injury and apoptosis facilitates crystal adhesion to cell surface, which serves as a key step in renal stone formation $[17,18]$. Khan, S. R. reveals that renal epithelial damage may assist in the formation of Randall's plaques [46]. Recently, Wang et al. find that COM crystals induced cytotoxicity and increased the lactate dehydrogenase (LDH) release in HK-2 cells [47]; $\mathrm{Hu}$ et al. also obtain similar results [48]. By the study of taurine interfered with calcium oxalate kidney stone model, some scholars find that the lower activity of mitochondrial antioxidant enzyme is related to the renal oxidative stress and the development of mitochondrial injury; meanwhile, the reason why taurine can protect the kidney may be related to the antioxidant effect of taurine itself [49]. When various causes lead to the activation of renal oxidative stress, it can lead to inflammation of renal tubular epithelial cells [50] and finally promote the accumulation of apatite deposits in the $\mathrm{RP}$ of renal tubular epithelial basement membrane. In addition, using the methods of optical microscope, transmission electron microscope, and Fourier transform infrared spectroscopy to analyze the biopsy specimens in patients with calculus, EVAN [51] discover a phenomenon that the epithelial cells at the attachment point of the stone were destroyed. The large accumulation of apatite in RP can change the physical and chemical environment of renal interstitium, calcify to RP, follow the flow of urine until to the kidney calices, and accumulate at the distal end small tube lumen. When the accumulation of HAP reaches a certain number, it can stimulate the hydrogenation of distal tubules, acidifying the urine, dissolving the calcium phosphate crystals at the end of the collection tube, releasing calcium and oxalate ions, forming calcium oxalate crystals, and finally cause the formation of calcium oxalate calculi.

At the same time, some scholars study the adhesion of the African green monkey renal epithelial cells with calcium oxalate and dihydrate calcium oxalate crystals before and after injury and the cellular response, they find that the adhesion and crystal concentration of calcium oxalate in the cells were positively correlated with the degree of cell damage. In the early stage, we also found significant calcium salt crystallization in renal tissue of renal calculi and showed obvious oxidative stress response due to cell injury [52], these indicate that oxidative stress and inflammatory injury are important reasons of the formation of urolithiasis.

Our current research is consistent with these conclusions. In our study, although macrophage cells cannot get through the membrane, they could interact with HK-2 cells by secreting inflammatory cytokines, such as C-C motif chemokine ligand 2 (CCL-2). From our ELISA results, we know that CCL-2 in the experimental groups increased in different degrees, HAP can stimulate the HK-2 cells to produce a certain amount of CCL-2, but the CCL-2 were mainly from the macrophages (Fig. 2). And by detecting the release of ROS, we find HAP can increase the fluorescence intensity of DCF in HK-2 cells, which up-regulate ROS in a time- and HAP concentration-dependent manner; macrophages can also exacerbate this enhancement effect. Therefore, we think that HAP can induce inflammation of HK-2 cells in a time- and HAP concentration-dependent manner, inflammatory factor released by macrophage cells can aggravate the inflammatory reaction through the microporous membrane, increase the expression of ROS, upgrade the oxidative stress reaction, and aggravate the damage of renal tubular epithelial cells. In addition, our LDH test results are further corroborating this phenomenon. LDH is an important enzyme in glycolysis, 
which exists in the cytoplasm of all tissues of the body and expresses higher in kidney. Cell damage may result in LDH release. And what we found was after co-culturing for 2, 4, and $6 \mathrm{~h}$, the LDH activity increased in the experimental groups compared with the control group, besides the $\mathrm{H}+\mathrm{M}$ group, the difference between the experimental group and the control group was statistically significant. It declares that after the stimulation of HAP, HK-2 cells damage broke, releasing LDH in a time- and HAP concentration-dependent manner, at the same time, macrophage cells can aggravate the increase of LDH. In our observation window, the relative expression of $\mathrm{LDH}$ was highest in $\mathrm{H}+\mathrm{M}+\mathrm{A} 2$ group after $6 \mathrm{~h}$ co-culture, indicating that the damage degree of HK-2 cells was also the most serious.

Our pre-study proved the cell apoptosis process can be activated after the renal tubular epithelial cells are damaged, this may increase the adhesion of crystal and the risk of stones formation [18].

From the western blotting analysis of BAX/BCL-2 (Fig. 7), we know the ratio of $B A X / B C L-2$ in the $\mathrm{H}+\mathrm{M}+\mathrm{A} 1$ group was higher than $\mathrm{H}+\mathrm{A} 1$ group after $6 \mathrm{~h}$ co-culture; therefore, we believe that macrophages can aggravate the apoptosis of renal tubular epithelial cells. More importantly, the results of our Flow Cytometry and DAPI staining also confirm that HAP and macrophages can induce and aggravate the damage of HK-2 cells. Using Flow Cytometry to detect the apoptosis rate of HK-2 cells, we find in the third quadrant, the positive rate of FITC and PI increases in different degrees compared with the control group (Fig. 8). This shows that in our in vitro co-culture model, HAP can increase the apoptosis of HK-2 cells in a time- and HAP concentration-dependent manner, and macrophages can increase the apoptosis of HK-2 cells induced by HAP. In addition, our DAPI staining results (Fig. 9) also show that the apoptosis rate of HK-2 cells is gradually increasing, which also confirms that macrophages have a certain regulatory effect on the damage of HK-2 cells induced by HAP. Therefore, it is not difficult to speculate that after HAP stimulates the renal tubular epithelial cells, the HK-2 cells are damaged and apoptotic, which is not only possible to expose phosphatidyl-serine (PS) to the cell surface $[53,54]$, and may also express kinds of crystal adhesion molecules such as HA, OPN, CD44, membrane protein II, glycoproteins containing sialic acids, and nucleolin-related proteins (NRP), these molecules have negative charge, which either can affect the oxalic acid root $\left(\mathrm{O}_{x}{ }^{2-}\right)$ role of calcium oxalate by hydrogen, or bond with calcium oxalate crystals by electrostatic interactions, thus greatly enhance the ability of the cells to bond to the crystal after cell damage. The damage of HAP to the renal tubular epithelial cells was further aggravated by the inflammatory factors secreted by macrophages, resulting in more calcium oxalate crystals attached to the renal tubular epithelial cells.

Fetuin-A, which is in sites of vascular calcification, has long been considered a powerful inhibitor of ectopic calcification and inflammation [55-60]. HAP acts as the plaque's main component in patients with kidney stones, and Fetuin-A also conducts to obtain a high affinity for HAP [10]. Marked extra-bone calcification has been remarkably reported in Fetuin-A knockout mice [20]. Normally, it seems that the kidney should have increased the expression of Fetuin-A to protect from the progress of inflammation induced by oxidative stress and overproduction of renal calcium. Nevertheless, interestingly, the previous studies [21, 52] imply that lower Fetuin-A protein level in urine and renal tissue may be one of the hazards for urolithiasis. Daveau, M regards Fetuin-A as a negative acutephase protein which can be down-regulated by cytokines [61]. Li et al. [62] also found that the early inflammatory cytokines could inhibit the expression of Fetuin-A. Our results were similar with these studies, but not with Aksoy [63]. As shown in Fig. 10, we detected the different degree of declining expression of Fetuin-A at different incubation period compared with the control, following with the upregulation of inflammatory cytokines. Especially, the expression of Fetuin-A in $\mathrm{H}+\mathrm{M}+\mathrm{A} 2$ group touched the bottom at $6 \mathrm{~h}$. These findings tell us after being stimulated by HAP, the HK-2 cells can down-regulate to express Fetuin-A in a time- and HAP concentration-dependent manner. At the same time, macrophages secrete a large number of CCL-2 which pass through the microporous membrane and aggravate the inflammatory response; this may be associated with the further decline of Fetuin-A in HK-2 cells. Some scholars find Fetuin-A has inhibitory effect on ectopic calcification and the deposition of calcium salt caused by apoptosis and inflammation induced by oxidative stress (OS) [55-57]. Consequently, we confirm that Fetuin-A may possibly inhibit OS. On the contrary, excessive OS induced by the increment of apoptosis, the up-regulation of OPN in HK-2 cells, the increased CCL-2 in medium mainly secreted by macrophage cells may possibly consume much of Fetuin-A, but the ability of the cell to secrete Fetuin-A is limited. When it exceeds the cell's secretion capacity, the expression of Fetuin-A shows a downward trend. Besides, apoptosis can also result in declining the ability of the HK-2 cells secreting Fetuin-A. However, this is just our supposition, further studies are needed to clarify the reasons of the decline of Fetuin-A.

In conclusion, in our in vitro co-culture model study, the stimulus of HAP can set off an inflammatory response in HK-2 cells, lead to apoptosis, increase the expression of OPN in HK-2 cells, and decline the expression of FetuinA. Especially, in the macrophage-renal tubular epithelial cell-HAP co-culture system, oxidative stress, the increase 
of inflammatory factor CCL-2 in renal tubular epithelial cells and cell apoptosis were more obvious, OPN went up more and Fetuin-A declined more dramatically. This shows that macrophages have a certain regulatory effect on the expression of HAP-induced inflammatory correlation factors in HK-2 cells. Therefore, we think that, on one hand, once the renal tubular epithelial cells occur inflammatory damage or trigger apoptosis process, not only does the release of reactive oxygen species increase, inflammatory factors and OPN protein secretion increase, intensifying the inflammation, causing the crystal adhesion, deposition, and heterogeneous nucleation, but also probably consume large amounts of Fetuin-A through oxidative stress and inflammatory response, inhibit the ability of HK-2 cells to secrete Fetuin-A, and decline the expression of Fetuin-A; however, the drop of Fetuin-A will decrease the body's ability of inhibiting the ectopic calcification, eventually promote the formation of stones. On the other hand, CCL-2 and OPN can also have a chemotactic effect on macrophage cells, which enhance the migration ability and phagocytic ability of macrophage cells. After swallowing the $\mathrm{CaO}_{x}$ crystals, macrophage cells can increase the expression of NAPDH oxidase in HK-2 cells, aggravate the inflammation, and induce the necrosis and denaturation of renal tubular epithelial cells; the basement membrane of renal tubular epithelial cells was exposed, thus promoting the formation of Randall plaques and even urolithiasis.

In consequence, if we can stop the release of the CCL2, OPN, and ROS, inhibit the oxidative stress and inflammatory injury and apoptosis of renal tubular epithelial cells caused by crystal reaction, and learn more about the regulation mechanism of Fetuin-A, it will help us to understand more about the formation mechanism of Randall's plaques, and may provide new ideas for further elaboration of the pathogenesis of urolithiasis.

However, given that this was only an in vitro study and we did not confirm our idea from animal models, it is difficult to determine whether our findings are the most representative of explanation for renal stone formation in human beings. In addition, we should not have been simply excluded the other kinds of crystals in renal interstitium from our study, like calcium oxalate. Moreover, we did not investigate the effect of inhibiting ROS generation on the expression of Fetuin-A. Furthermore, it was absent of direct evidences whether the cell damage resulted from the HAP and macrophage cell-induced inflammation can promote crystal adherence and deposition in HK-2 cells. Eventually, further studies are also needed to determine whether there is some kind of mechanism that can regulate the expression of Fetuin-A in kidney and can protect renal tubular epithelial cell against apoptosis. We need further study to compensate for our weaknesses.

\section{Compliance with ethical standards}

Funding This study was funded by the National Natural Science Foundation of China (No. 81360113, 30860280, 30960455, 81760127).

Conflict of interest The entire author declares that he/she has no conflict of interest.

Ethical approval This article does not contain any studies with human participants or animals performed by any of the authors.

Open Access This article is distributed under the terms of the Creative Commons Attribution 4.0 International License (http://creativecommons.org/licenses/by/4.0/), which permits unrestricted use, distribution, and reproduction in any medium, provided you give appropriate credit to the original author(s) and the source, provide a link to the Creative Commons license, and indicate if changes were made.

\section{References}

1. Moe OW (2006) Kidney stones: pathophysiology and medical management. Lancet (London England) 367:333-344

2. Antonelli JA, Maalouf NM, Pearle MS, Lotan Y (2014) Use of the National Health and Nutrition Examination Survey to calculate the impact of obesity and diabetes on cost and prevalence of urolithiasis in 2030. Eur Urol 66:724-729

3. El-Zoghby ZM, Lieske JC, Foley RN, Bergstralh EJ, Li X, Melton LJ 3rd, Krambeck AE, Rule AD (2012) Urolithiasis and the risk of ESRD Clin. J Am Soc Nephrol 7: 1409-1415

4. Kohjimoto Y, Sasaki Y, Iguchi M, Matsumura N, Inagaki T, Hara I (2013) Association of metabolic syndrome traits and severity of kidney stones: results from a nationwide survey on urolithiasis in Japan. Am J Kidney Dis 61:923-929

5. Dardamanis M (2013) Pathomechanisms of nephrolithiasis. Hippokratia 17:100-107

6. Mandal T, Ward MD (2013) Determination of specific binding interactions at L-cystine crystal surfaces with chemical force microscopy. J Am Chem Soc 135:5525-5528

7. Daudon M, Bazin D, Letavernier E (2015) Randall's plaque as the origin of calcium oxalate kidney stones. Urolithiasis 43(Suppl 1):5-11

8. Randall A (1937) The origin and growth of renal calculi. Ann Surg 105:1009-1027

9. Kim SC, Coe FL, Tinmouth WW, Kuo RL, Paterson RF, Parks JH, Munch LC, Evan AP, Lingeman JE (2005) Stone formation is proportional to papillary surface coverage by Randall's plaque. J Urol 173:117-119 (discussion 119)

10. Verrier C, Bazin D, Huguet L, Stephan O, Gloter A, Verpont MC, Frochot V, Haymann JP, Brocheriou I, Traxer O, Daudon M, Letavernier E (2016) Topography, composition and structure of incipient Randall plaque at the nanoscale level. J Urol 196:1566-1574

11. de Water R, Noordermeer C, van der Kwast TH, Nizze H, Boeve ER, Kok DJ, Schroder FH (1999) Calcium oxalate nephrolithiasis: effect of renal crystal deposition on the cellular composition of the renal interstitium. Am J Kidney Dis 33:761-771

12. Zuo L, Tozawa K, Okada A, Yasui T, Taguchi K, Ito Y, Hirose Y, Fujii Y, Niimi K, Hamamoto S, Ando R, Itoh Y, Zou J, Kohri K (2014) A paracrine mechanism involving renal tubular cells, adipocytes and macrophages promotes kidney stone 
formation in a simulated metabolic syndrome environment. J Urol 191:1906-1912

13. Khan SR (2013) Reactive oxygen species as the molecular modulators of calcium oxalate kidney stone formation: evidence from clinical and experimental investigations. J Urol 189:803-811

14. Okada A, Yasui T, Fujii Y, Niimi K, Hamamoto S, Hirose M, Kojima Y, Itoh Y, Tozawa K, Hayashi Y, Kohri K (2010) Renal macrophage migration and crystal phagocytosis via inflammatory-related gene expression during kidney stone formation and elimination in mice: detection by association analysis of stonerelated gene expression and microstructural observation. J Bone Miner Res 25:2701-2711

15. Martinez FO, Gordon S (2014) The M1 and M2 paradigm of macrophage activation: time for reassessment. F1000prime Rep 6:13

16. Anderson CF, Mosser DM (2002) A novel phenotype for an activated macrophage: the type 2 activated macrophage. J Leukoc Biol 72:101-106

17. Gan QZ, Sun XY, Bhadja P, Yao XQ, Ouyang JM (2016) Reinjury risk of nano-calcium oxalate monohydrate and calcium oxalate dihydrate crystals on injured renal epithelial cells: aggravation of crystal adhesion and aggregation. Int J Nanomed 11:2839-2854

18. Wang Y, Sun C, Li C, Deng Y, Zeng G, Tao Z, Wang X, Guan $X$, Zhao Y (2016) Urinary MCP-1HMGB1 increased in calcium nephrolithiasis patients and the influence of hypercalciuria on the production of the two cytokines. Urolithiasis 45:159-175

19. Khan SR (2014) Reactive oxygen species, inflammation and calcium oxalate nephrolithiasis. Transl Androl Urol 3:256-276

20. Seto J, Busse B, Gupta HS, Schafer C, Krauss S, Dunlop JW, Masic A, Kerschnitzki M, Zaslansky P, Boesecke P, Catala-Lehnen P, Schinke T, Fratzl P, Jahnen-Dechent W (2012) Accelerated growth plate mineralization and foreshortened proximal limb bones in fetuin-A knockout mice. PloS One 7:e47338

21. Stejskal D, Karpisek M, Vrtal R, Student V, Solichova P, Fiala R, Stejskal P (2008) Urine fetuin-A values in relation to the presence of urolithiasis. BJU Int 101:1151-1154

22. Aihara K, Byer KJ, Khan SR (2003) Calcium phosphate-induced renal epithelial injury and stone formation: involvement of reactive oxygen species. Kidney Int 64:1283-1291

23. Wang B, Zhang A, Zheng J, Gong J, Li S, Zeng Z, Gan W (2011) Bufalin inhibits platelet-derived growth factor-BB-induced mesangial cell proliferation through mediating cell cycle progression. Biol Pharm Bull 34:967-973

24. Lee KE, Kim EY, Kim CS, Choi JS, Bae EH, Ma SK, Kim KK, Lee JU, Kim SW (2013) Macrophage-stimulating protein attenuates gentamicin-induced inflammation and apoptosis in human renal proximal tubular epithelial cells. Biochem Biophys Res Commun 434:527-533

25. Bae EH, Cho S, Joo SY, Ma SK, Kim SH, Lee J, Kim SW (2011) 4-Hydroxy-2-hexenal-induced apoptosis in human renal proximal tubular epithelial cells. Nephrol Dial Transpl 26:3866-3873

26. Sugimoto MA, Ribeiro AL, Costa BR, Vago JP, Lima KM, Carneiro FS, Ortiz MM, Lima GL, Carmo AA, Rocha RM, Perez DA, Reis AC, Pinho V, Miles LA, Garcia CC, Teixeira MM, Sousa LP (2017) Plasmin and Plasminogen induce macrophage reprogramming and regulate key steps of inflammation resolution via Annexin A1. Blood 129:2896-2907

27. Hardbower DM, Coburn LA, Asim M, Singh K, Sierra JC, Barry DP, Gobert AP, Piazuelo MB, Washington MK, Wilson KT (2017) EGFR-mediated macrophage activation promotes colitisassociated tumorigenesis. Oncogene 36:3807-3819

28. Chung HJ (2014) The role of Randall plaques on kidney stone formation. Transl Androl Urol 3:251-254

29. Evan AP, Worcester EM, Williams JC Jr, Sommer AJ, Lingeman JE, Phillips CL, Coe FL (2015) Biopsy proven medullary sponge kidney: clinical findings, histopathology, and role of osteogenesis in stone and plaque formation. Anatom Rec (Hoboken, NJ: 2007) 298:865-877

30. Fujii Y, Okada A, Yasui T, Niimi K, Hamamoto S, Hirose M, Kubota Y, Tozawa K, Hayashi Y, Kohri K (2013) Effect of adiponectin on kidney crystal formation in metabolic syndrome model mice via inhibition of inflammation and apoptosis. PloS One 8:e61343

31. Griffiths HR, Gao D, Pararasa C (2017) Redox regulation in metabolic programming and inflammation. Redox Biol 12:50-57

32. de Water R, Noordermeer C, Houtsmuller AB, Nigg AL, Stijnen T, Schroder FH, Kok DJ (2000) Role of macrophages in nephrolithiasis in rats: an analysis of the renal interstitium. Am J Kidney Dis 36:615-625

33. Kanlaya R, Sintiprungrat K, Thongboonkerd V (2013) Secreted products of macrophages exposed to calcium oxalate crystals induce epithelial mesenchymal transition of renal tubular cells via RhoA-dependent TGF-beta1 pathway. Cell Biochem Biophys 67:1207-1215

34. Pyzer AR, Stroopinsky D, Rajabi H, Washington A, Tagde A, Coll M, Fung J, Bryant MP, Cole L, Palmer K, Somaiya P, Leaf RK, Nahas M, Apel A, Jain S, McMasters M, Mendez L, Levine J, Joyce R, Arnason J, Pandolfi PP, Kufe D, Rosenblatt J, Avigan D (2017) MUC1 mediated induction of myeloid-derived suppressor cells in patients with acute myeloid leukemia. Blood 129:1791-1801

35. Ueda K, Beppu T (2017) Antibiotics in microbial coculture. J Antibiot 70:361-365

36. Kerneis S, Caliot E, Stubbe H, Bogdanova A, Kraehenbuhl J, Pringault E (2000) Molecular studies of the intestinal mucosal barrier physiopathology using cocultures of epithelial and immune cells: a technical update. Microbes Infect 2:1119-1124

37. Alex M, Sauganth Paul MV, Abhilash M, Mathews VV, Anilkumar TV, Nair RH (2014) Astaxanthin modulates osteopontin and transforming growth factor beta1 expression levels in a rat model of nephrolithiasis: a comparison with citrate administration. BJU Int 114:458-466

38. Langdon A, Grohe B (2016) The osteopontin-controlled switching of calcium oxalate monohydrate morphologies in artificial urine provides insights into the formation of papillary kidney stones. Colloids Surf B Biointerfaces 146:296-306

39. Taguchi K, Hamamoto S, Okada A, Unno R, Kamisawa H, Naiki T, Ando R, Mizuno K, Kawai N, Tozawa K, Kohri K, Yasui T (2016) Genome-wide gene expression profiling of Randall's plaques in calcium oxalate stone. JASN 28:333-347

40. Thurgood LA, Sorensen ES, Ryall RL (2012) The effect of intracrystalline and surface-bound osteopontin on the degradation and dissolution of calcium oxalate dihydrate crystals in MDCKII cells. Urol Res 40:1-15

41. Hirose M, Tozawa K, Okada A, Hamamoto S, Higashibata $Y$, Gao B, Hayashi Y, Shimizu H, Kubota Y, Yasui T, Kohri K (2012) Role of osteopontin in early phase of renal crystal formation: immunohistochemical and microstructural comparisons with osteopontin knock-out mice. Urol Res 40:121-129

42. Scanu A, Luisetto R, Oliviero F, Gruaz L, Sfriso P, Burger D, Punzi L (2015) High-density lipoproteins inhibit urate crystalinduced inflammation in mice. Ann Rheum Dis 74:587-594

43. Dhanasekar C, Kalaiselvan S, Rasool M (2015) Morin, a bioflavonoid suppresses monosodium urate crystal-induced inflammatory immune response in RAW 264.7 macrophages through the inhibition of inflammatory mediators, intracellular ROS levels and NF-kappaB activation. PloS One 10:e0145093

44. Peng Z, Chen W, Wang L, Ye Z, Gao S, Sun X, Guo Z (2015) Inhalation of hydrogen gas ameliorates glyoxylate-induced calcium oxalate deposition and renal oxidative stress in mice. Int $\mathrm{J}$ Clin Exp Pathol 8:2680-2689 
45. Ichikawa J, Okada A, Taguchi K, Fujii Y, Zuo L, Niimi K, Hamamoto S, Kubota Y, Umemoto Y, Itoh Y, Yasui T, Kawai N, Tozawa K, Kohri K (2014) Increased crystal-cell interaction in vitro under co-culture of renal tubular cells and adipocytes by in vitro coculture paracrine systems simulating metabolic syndrome. Urolithiasis 42:17-28

46. Khan SR (2011) Crystal/cell interaction and nephrolithiasis. Archivio italiano di urologia, andrologia: organo ufficiale [di] Societa italiana di ecografia urologica e nefrologica/Associazione ricerche in urologia $83: 1-5$

47. Wang B, Wu B, Liu J, Yao W, Xia D, Li L, Chen Z, Ye Z, Yu $X$ (2014) Analysis of altered microRNA expression profiles in proximal renal tubular cells in response to calcium oxalate monohydrate crystal adhesion: implications for kidney stone disease. PloS One 9:e101306

48. Hu B, Wu HR, Ma ZY, Wu ZC, Lu YM, Shi GW (2014) Involvement of VKORC1 in the inhibition of calcium oxalate crystal formation in HK-2 cells. J Huazhong Univ Sci Technol Med Sci 34:376-381

49. Li CY, Deng YL, Sun BH (2009) Taurine protected kidney from oxidative injury through mitochondrial-linked pathway in a rat model of nephrolithiasi. Urol Res 37:211-220

50. Khan SR (2012) Is oxidative stress, a link between nephrolithiasis and obesity, hypertension, diabetes, chronic kidney disease, metabolic syndrome? Urol Res 40:95-112

51. Evan AP, Unwin RJ, Williams JC Jr (2011) Renal stone disease: a commentary on the nature and significance of Randall's plaque. Nephron Physiol 119:49-53

52. Wu YX, Li CY, Deng YL (2014) Patients with nephrolithiasis had lower fetuin-A protein level in urine and renal tissue. Urolithiasis 42:29-37

53. Kittikowit W, Waiwijit U, Boonla C, Ruangvejvorachai P, Pimratana C, Predanon C, Ratchanon S, Tosukhowong P (2014) Increased oxidative DNA damage seen in renal biopsies adjacent stones in patients with nephrolithiasis. Urolithiasis 42:387-394

54. Lang F, Abed M, Lang E, Foller M (2014) Oxidative stress and suicidal erythrocyte death. Antioxid Redox Signal 21:138-153

55. Wolk K, Sabat R (2016) Adipokines in psoriasis: an important link between skin inflammation and metabolic alterations Rev Endocr Metab Disord 17:305-317
56. Ombrellino M, Wang H, Yang H, Zhang M, Vishnubhakat J, Frazier A, Scher LA, Friedman SG, Tracey KJ (2001) Fetuin, a negative acute phase protein, attenuates TNF synthesis and the innate inflammatory response to carrageenan. Shock (Augusta Ga) 15:181-185

57. Kahraman A, Sowa JP, Schlattjan M, Sydor S, Pronadl M, Wree A, Beilfuss A, Kilicarslan A, Altinbas A, Bechmann LP, Syn WK, Gerken G, Canbay A (2013) Fetuin-A mRNA expression is elevated in NASH compared with NAFL patients. Clin Sci (Lond) 125:391-400

58. Janda K, Krzanowski M, Gajda M, Dumnicka P, Jasek E, Fedak D, Pietrzycka A, Kuzniewski M, Litwin JA, Sulowicz W (2015) Vascular effects of advanced glycation end-products: content of immunohistochemically detected AGEs in radial artery samples as a predictor for arterial calcification and cardiovascular risk in asymptomatic patients with chronic kidney disease. Dis Mark 2015:153978

59. Paloian NJ, Giachelli CM (2014) A current understanding of vascular calcification in CKD. Am J Physiol Renal Physiol 307:F891-F900

60. Schinke T, Amendt C, Trindl A, Poschke O, Muller-Esterl W, Jahnen-Dechent W (1996) The serum protein alpha2-HS glycoprotein/fetuin inhibits apatite formation in vitro and in mineralizing calvaria cells. A possible role in mineralization and calcium homeostasis. J Biol Chem 271:20789-20796

61. Daveau M, Christian D, Julen N, Hiron M, Arnaud P, Lebreton JP (1988) The synthesis of human alpha-2-HS glycoprotein is down-regulated by cytokines in hepatoma HepG2 cells. FEBS Lett 241:191-194

62. Li W, Zhu S, Li J, Huang Y, Zhou R, Fan X, Yang H, Gong X, Eissa NT, Jahnen-Dechent W, Wang P, Tracey KJ, Sama AE, Wang H (2011) A hepatic protein, fetuin-A, occupies a protective role in lethal systemic inflammation. PloS One 6:e16945

63. Aksoy H, Aksoy Y, Ozturk N, Aydin HR, Yildirim AK, Akcay F (2010) Fetuin-A gene polymorphism in patients with calcium oxalate stone disease. Urology 75:928-932

\section{Affiliations}

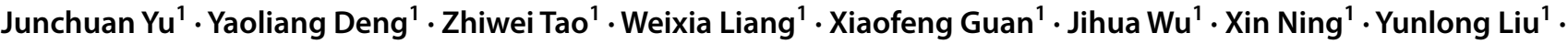 Quan Liu' ${ }^{1}$ Ziqi He ${ }^{1}$}

Yaoliang Deng

dylkf317@163.com

Weixia Liang

liangweixia2004@163.com
1 Department of Urology, The First Affiliated Hospital of Guangxi Medical University, Nanning 530021, China 